\title{
Beyond the FANTOM4
}

Harukazu Suzuki ${ }^{*}$ Piero Carninci, Carsten Daub, Jun Kawai, Yoshihide Hayashizaki

From Beyond the Genome: The true gene count, human evolution and disease genomics Boston, MA, USA. 11-13 October 2010

RIKEN OSC has a long history of transcriptome analysis using DNA sequencers; we also organize the international consortium Functional Annotation of Mammalian Genome (FANTOM; Figure 1). We have developed a novel method Cap Analysis of Gene Expression (CAGE), which analyzes capped transcripts in a genome-wide manner by sequencing the 5' end of mRNA. In the recently completed FANTOM4, we analyzed the transcriptional regulation network of human THP-1 cell differentiation at the promoter level with deepCAGE, an

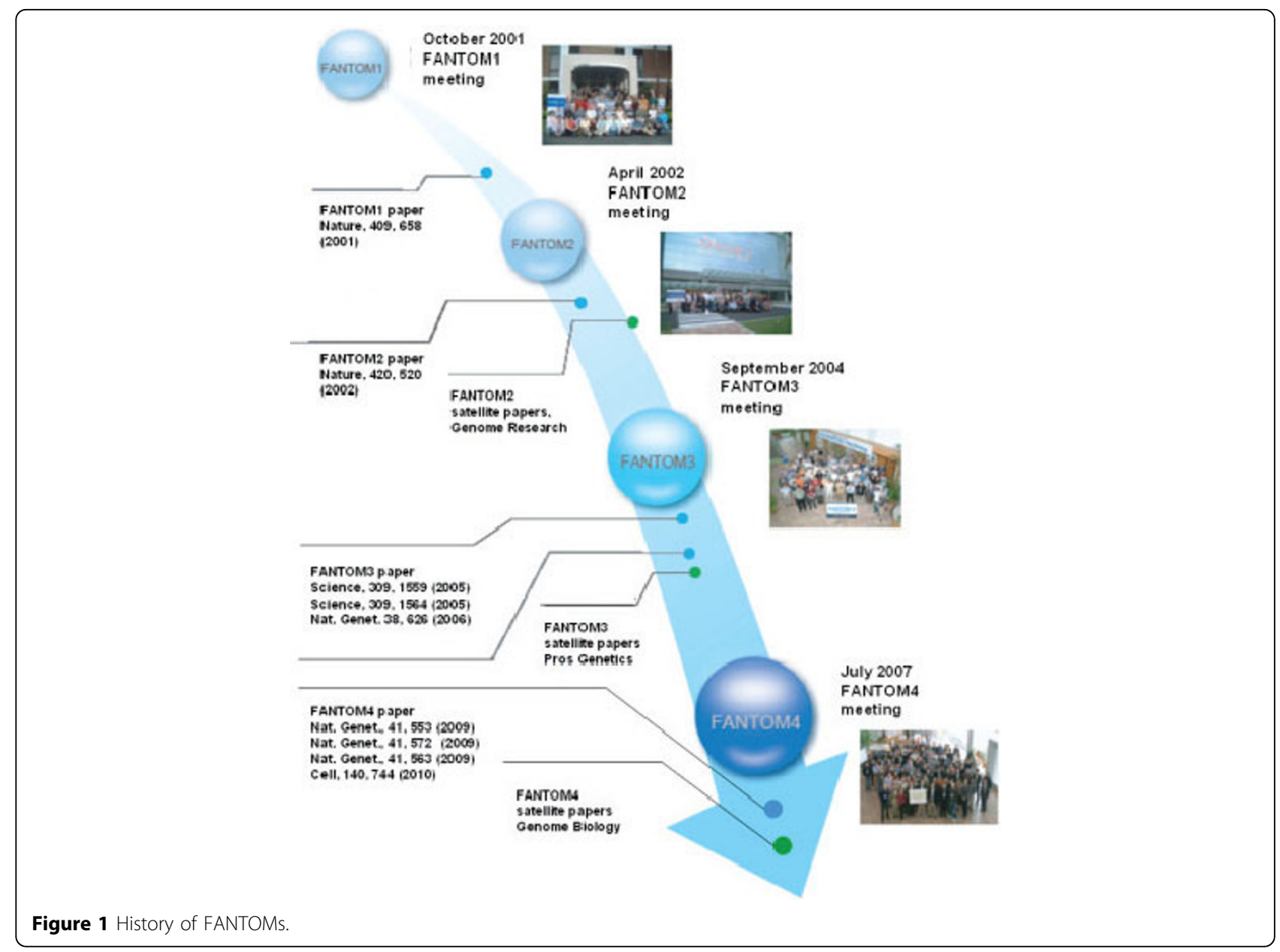

RIKEN Omics Science Center (OSC), Yokohama, 230-0045, Japan 
application of CAGE for the next-generation sequencers. The deepCAGE data were also used to analyze the promoter activity of repeat elements and to discover new small RNA (tiRNA) by integration with the small RNA sequencing.

Although the deepCAGE is a powerful tool for transcriptome analysis, it is limited owing to the need to use a significantly large amount of RNA and it is semi-quantitative. We have addressed these problems and developed NanoCAGE technology and quantitative deepCAGE. OSC aims to expand transcriptome knowledge; we aim to understand promoter and transcriptional regulation. We are about to start the FANTOM5 project.

Published: 11 October 2010

doi:10.1186/gb-2010-11-S1-011

Cite this article as: Suzuki et al:: Beyond the FANTOM4. Genome Biology 201011 (Suppl 1):O11.
Submit your next manuscript to BioMed Central and take full advantage of:

- Convenient online submission

- Thorough peer review

- No space constraints or color figure charges

- Immediate publication on acceptance

- Inclusion in PubMed, CAS, Scopus and Google Scholar

- Research which is freely available for redistribution

Submit your manuscript at www.biomedcentral.com/submit 